\title{
The Effect of Bank Credibility and Service Convenience on Bank Customer Attitudes
}

\author{
Esya Alhadi ${ }^{1, *}$ Gusti Ayu Oka Windarti ${ }^{1}$ Elvia Zahara ${ }^{1}$ Titi Andriani ${ }^{1}$ \\ ${ }^{1}$ Business Administration Department, State Polytechnic of Sriwijaya \\ ${ }^{*}$ Corresponding author. Email: esyaalhadi63@gmail.com
}

\begin{abstract}
Electronic banking services have developed and are implemented by the banking sector in providing services to customers. It is interesting to study the drivers of customer behavior in using electronic banking services. Therefore, this study seeks to determine the drivers of consumer attitudes in using services of bank. The number of customers who became research respondents was 164 people. The side technique used was purposive sampling. The findings of the study explain that bank credibility is not a driving force for customers' attitude to act in using banking services. Then, the convenience of banking services felt by customers becomes a trigger customers' attitude for using banking services. These findings are expected to contribute to knowledge, especially in the banking sector.
\end{abstract}

Keywords: bank credibility, service convenience, costumer attitude.

\section{INTRODUCTION}

Dramatic changes have been experienced by the banking business sector in the last few decades. The development of technology, especially computer, communication and information technology, has encouraged changes in banking services to consumers. Electronic services that are relatively cheap and fast are used by the banking sector and other financial institutions [1]. Internet-based services, especially mobile-based services, have become the most important services provided by banking businesses and other financial institutions [2]. Electronic banking services provide many benefits and conveniences for banks and consumers. Bank managers can provide services to customers and related parties with a variety of features such as security and ease of use of banking services.

[3] explains that electronic banking services will present a unique experience to customers. In addition, this service has reliability to monitor financial assets quickly and accurately. Bank managers also use electronic banking services to reduce operational costs and service coverage. Changes in the form of services used by banking managers will also have an impact on customers. This is driven by the habit of customers using conventional forms of banking services, where clients associate with and deal with employees of bank. [4] explained that electronic banking will have an impact on the risks faced by customers. [5] stated that the banking sector in the early days of business relied on manual activity for a little number of goods and merits. The need for automation comes with increased sophistication, data volume, complexity and cost benefits in a variety of products and services. The high demand for technology goods and merits encourages contention and lead deftness and retrenchment to regular bank output and services. Electronic banking services are generally believed to have a positive effect on profitability and performance but require large costs associated with technological infrastructure. The costs associated with electronic banking including infrastructure, ongoing maintenance and employee training are higher than income from electronic services [6]. 


\section{LITERATURE REVIEW}

Bank Credibility and Costumer Attitudes

Credibility is related to individual perceptions that transactions and information privacy are managed safely and reliably and will encourage acceptance of technological systems [7]. Perceptions of credibility are believed to have an empirical impact on consumer acceptance [7]. [8] describes that security is related to the protection of information systems from unauthorized users. Privacy and security are an important part of credibility, and have become a study to measure the acceptance of banking technology [9]. The studies of [10], [11], and [12] found that credibility perception hold a good effect on the inclination of consumers to use and adopt electronic banking. A study by [13] explains that electronic banking customers want bank services to provide security guarantees in financial transactions and maintain the confidentiality of individual information. The results of [14] study also show that perceived credibility is well related to perceived benefits and perception ease of use.

Service Convenience and Costumer Attitude

[15] explained that service convenience is closely related to perceived benefits. However, other research on electronic banking adoption did not find a close relationship between concept of service convenience and the behavioral interest in using services. [16] explains that convenience is indirectly related to user behavior interest in adopting services through perceived ease of use. [17] stated that the service convenience factor attracts interest in using electronic payment services.

\section{METHODS}

\section{Research population}

Population of recent study were customers from 4 banks in the city of Palembang, namely BNI, BRI, Bank Mandiri, and BCA. The selection of the 4 banks was based on the quality and variety of services based on electronic banking services provided to consumers and customers which were relatively complete. Purposive Sampling technique is used in this research to determine which customers will be research respondents. The respondents of this study were 164 customers of 4 banks conducting business activities in the city of Palembang.

\section{Analysis of Data}

Analysis of statistical method use path analysis with SPSS for windows version 22.00. Path analysis is able to calculate the quantitative linear link among the variables of research.

\section{RESULTS}

\section{Respondent Description}

Male respondents were 78 people or $47.6 \%$ and female respondents were 86 people or $52.4 \%$. respondents age 17-24 years amounted to 3 people or $1.8 \%, 3$ people age $25-29$ or $1.8 \%, 12$ people age $30-35$ or $7.3 \%$, ages $36-41$ years 43 people or equal to $26.2 \%$, and those age > 41 years were 103 people or $62.8 \%$. Respondents with PNS jobs were 127 people or $77.4 \%$, private employees were 13 people or $7.9 \%$, entrepreneurial jobs were 7 people or $4.3 \%$, student were 3 people or $1.8 \%$ and other jobs were 14 people or $8.5 \%$. respondents who used the service for $<1$ year were 13 people or $7.9 \%$, 30 people used the service for $1-3$ years or $18.3 \%$, and used the service for $>3$ years 121 people or $73.8 \%$

\section{Validity and Reliability Test}

Based on data testing from the results of the questionnaire, it is known that each question item for each variable has $r$ count $>0.1533$ This indicates that all the question items tested are valid. Reliability test shows that the overall value of Cronbach $\alpha$ research variable is declared good, where the value is above 0.60 so that it can be stated that all indicators used are reliable.

Path Analysis

The results of data analysis on the bank credibility variable explained that the value of $t$ count $=-0.623$ and $\beta=-0.024$ with a significance level of 0.534 . This explains that statistically using a research value level of 0.05 , grade of 0.534 is higher than the $5 \%$ level, so it can be stated that bank credibility has no significant and positive impact on customer attitudes. This study is different from previous research conducted by [18]; [7]; [12]; [19]; [11]; [20] stated that bank credibility is the driving force for customer attitudes to use banking services. The originate in investigation explain that individual in using electronic banking services do not dominantly consider the good name of a bank.

The results of data analysis on the service convenience variable explained that the $\mathrm{t}$ value $=5.307$ and $\beta=0.318$ with a value level of 0.000 . This explains that statistically using a research significance level of 0.05 , the significance grade of 0.000 is smaller than the $5 \%$ level, so it can be stated that service convenience has a important and positive effect on individual attitudes. This study supports the research conducted by [21]; [22]; [23]; [15]; [24], which states that the convenience of service felt by bank customers will encourage customers to be better at using service of banking based on electronic. The outcome of research explained that higher the level of comfort felt by customers, the better the customer's attitude in using electronic banking services. 
Table 1 validity measurement

\begin{tabular}{|c|c|c|c|}
\hline Variable & Ind & Validity & Statement \\
\hline \multirow{4}{*}{$\begin{array}{l}\text { Bank } \\
\text { Credibility }\end{array}$} & $\mathrm{BC}_{1}$ & 0.843 & Valid \\
\hline & $\mathrm{BC}_{2}$ & 0.942 & Valid \\
\hline & $\mathrm{BC}_{3}$ & 0.852 & Valid \\
\hline & $\mathrm{BC}_{4}$ & 0.890 & Valid \\
\hline \multirow{4}{*}{$\begin{array}{l}\text { Service } \\
\text { Convenience }\end{array}$} & $\mathrm{SC}_{1}$ & 0.878 & Valid \\
\hline & $\mathrm{SC}_{2}$ & 0.887 & Valid \\
\hline & $\mathrm{SC}_{3}$ & 0.838 & Valid \\
\hline & $\mathrm{SC}_{4}$ & 0.818 & Valid \\
\hline \multirow{3}{*}{$\begin{array}{l}\text { Costumer } \\
\text { Attitude }\end{array}$} & $\mathrm{CA}_{1}$ & 0.800 & Valid \\
\hline & $\mathrm{CA}_{2}$ & 0.878 & Valid \\
\hline & $\mathrm{CA}_{3}$ & 0.848 & Valid \\
\hline
\end{tabular}

Table 2 reliability measurement

\begin{tabular}{|l|l|l|}
\hline Variable & Reliability & Statement \\
\hline Bank Credibility & 0.897 & Reliable \\
\hline $\begin{array}{l}\text { Service } \\
\text { Convenience }\end{array}$ & 0.875 & Reliable \\
\hline Costumer Attitude & 0.791 & Reliable \\
\hline
\end{tabular}

Table 3 path measurement

\begin{tabular}{|c|c|c|c|c|}
\hline Independent & Dependent & B & t-value & Sig. \\
\hline $\begin{array}{l}\text { Bank } \\
\text { Credibility }\end{array}$ & $\begin{array}{l}\text { Costumer } \\
\text { Attitude }\end{array}$ & -0.024 & -.623 & 0.534 \\
\hline $\begin{array}{l}\text { Service } \\
\text { Convenience }\end{array}$ & $\begin{array}{l}\text { Costumer } \\
\text { Attitude }\end{array}$ & 0.318 & 5.307 & 0.000 \\
\hline \multicolumn{2}{|c|}{ Constanta $=2.506$} & & & \\
\hline \multicolumn{2}{|c|}{ R.Square $=.683$} & & & \\
\hline \multicolumn{2}{|c|}{ Adj. R.Square $=.677$} & & & \\
\hline \multicolumn{2}{|c|}{ F. statistic $=114.723$} & & & \\
\hline \multicolumn{2}{|c|}{ Significance $=0.000$} & & & \\
\hline
\end{tabular}

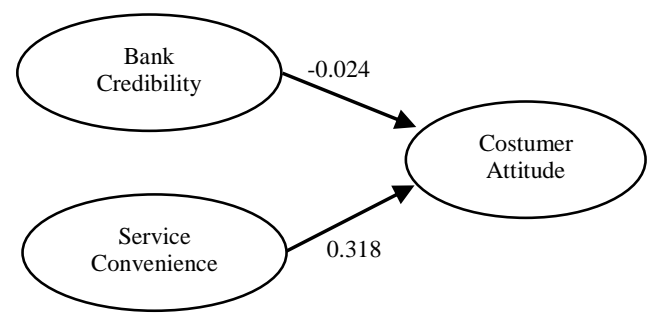

Figure 1 Path Analysis Result

\section{CONCLUSIONS}

The study of bank clients explained that the linkage among bank credibility, service convenience and costumer attitude have different output. Outcome of the survey showed that the bank credibility has not a strong effect on costumer attitude. Then, service convenience has a strong effect on costumer attitude. Based on the proof, management of banks should have the capability to identify the element that could be a driver for customers' attitude to use bank services.

\section{REFERENCES}

[1] Suoranta, M., and Mattila, M. 2004. "Mobile banking and consumer behaviour: new insights into the diffusion pattern", Journal of Financial Services Marketing, Vol. 8 No. 4: pp. 354-66.

[2] Mallat, N., Rossi, M., and Tuunainen, V. K. 2004. "Mobile banking services". Communications of the $A C M$, Vol. 47 No. 5: pp. 42-46.

[3] Alalwan, A. A., Dwivedi, Y. K., Rana, N. P., and Algharabat, R. 2018. "Examining factors influencing Jordanian customers' intentions and adoption of internet banking: Extending UTAUT2 with risk". Journal of Retailing and Consumer Services, Vol. 40: pp. 125-138.

[4] Salhieh, L., Abu-Doleh, J., and Hijazzi, N. 2011. "The Assessment of E-banking Readiness in Jordan", The International Journal of Islamic and Middle Eastern Financial Management, Vol.4, No. 4: pp. 325-342.

[5] Khir, K., Lobesh, G., and Bala, S. 2009. Islamic Banking: A Practical Perspective, Pearson Longman, Second Edition.

[6] Al-Smadi, Mohammad. O., and Saad, A. AlWabel. 2011. "The Impact of E-Banking on the Performance of Jordanian Banks", Journal of Internet Banking and Commerce, Vol. 16 No. 2: pp. 1-10.

[7] Wang, Y.S, Wang, Y.M, Lin, H.H., and Tang, T.I. 2003. "Determinants of user acceptance of internet banking: An empirical Study". International journal of Service Industry management, Vol.14, No. 5: pp. 501.

[8] Egwali, A. O. 2008. "Customer Perception of Security Indicators in Online Banking Sites in Nigeria", Journal of Internet Banking and Commerce, Vol. 13 No.3

[9] Hanafizadeh, P., Behboudi, M., Koshksaray, A.A., and Tabar, S.M.J. 2014. "Mobile-banking adoption by Iranian bank clients", Journal Telematics and Informatics, Vol. 31 No.1: pp. 62-78.

[10] Jeong, B.K., and Yoon, T.E., 2013. An Empirical Investigation on Consumer Acceptance of Mobile Banking Services. Business and Management Research, Vol. 2 No. 1: pp.31-40.

[11] Wang, Y.S., Lin, H.H., and Luarn, P. 2006. "Predicting consumer intention to use mobile service". Information Systems Journal, Vol. 2: pp.157-179.

[12] Luarn, P., and Lin, H.H. 2005. "Toward an understanding of the behavioral intention to use mobile banking". Computers in Human Behavior, Vol. 21 No. 6: pp.873-891. 
[13] Amin, H., Baba, R., and Muhammad, Z. M. 2007. "An analysis of mobile banking acceptance by Malaysian customers", Sunway Academic Journal, Vol. 4: pp. 1-12.

[14] Karjaluoto, H., Mattila, M., and Pento, T. 2002. "Factors Underlying Attitude Formation towards Online Banking in Finland", International Journal of Bank Marketing, Vol. 20 No. 6: pp.261-272.

[15] Dalhatu, B.U., Abdullah, A.B., M Yussoff Ibrahim, M.Y., and Abideen, A. 2014. "Nigerian retail customers' adoption of online banking in an islamic bank". Global Business and Management Research: An International Journal, Vol. 6 No. 3: pp.237-245.

[16] Tang, J.T.E., and Chiang, C. 2009. "Towards an understanding of the behavioral intention to use mobile knowledge management". WSEAS Transactions on Information Science and Applications, Vol. 6 No. 9: pp.1601-1613.

[17] Kim, C., Mirusmonov, M. and Lee, I., 2010. “An empirical examination of factors influencing the intention to use mobile payment". Computers in Human Behavior, Vol. 26 No. 3: pp.310-322

[18] Carter, L., and Bélanger, F. 2005. "The utilization of e-government services: citizen trust, innovation and acceptance factors". Information Systems Journal, Vol.15: pp.5-26.

[19] Gefen, D., Karahanna, E., and Straub, D.W. 2003. "Inexperience and experience with online stores: the importance of TAM and trust". IEEE Trans Eng Manage, 50: pp.307-321

[20] Lin, F.T., Wu, H.Y., and Tran, T.N.N. 2014. "Internet banking adoption in a developing country: an empirical study in Vietnam". Information Systems and e-Business Management, Vol. 13 No. 2: pp.267-287.

[21] Clarke, I. III. 2001. "Emerging value propositions for m-commerce". Journal of Business Strategies, Vol.18, 133-148.

[22] Ding, X., Ijima, J., and Ho, S. 2004. "Unique features of mobile commerce". Tokyo 152-8552, Japan: Graduate School of Decision Science and Technology, TITECH.

[23] Xu, G., and Gutierrez, J. A. 2006. “An Exploratory study of killer applications and critical success: Factors in M-commerce". Journal of Electronic Commerce in Organizations, Vol. 4 No. 4: pp. 63 79.

[24] Liu, G.S., and Tai, P.T. 2016. A Study of Factors Affecting the Intention to Use Mobile Payment Services in Vietnam. Economics World, Nov.-Dec. 2016, Vol. 4, No. 6: pp.249-273 